\title{
PERANCANGAN DAN PENGEMBANGAN PRODUK DAUN PINTU UKIRAN YANG BERORIENTASI PADA PREFERENSI KONSUMEN DENGAN KONSEP REKAYASA NILAI
}

\author{
Titik Noorida ${ }^{1}$, Soffa $^{2}$
}

\begin{abstract}
The grouith of Jepara traditional architecture that begins too advanced now days had caused appearing ideas for the writer to creat design creation from Jepara architecture building component that is modern traditional.

Desaigning and developing Jepara architecture component production is especiallied on a door carving only. The creation that will be developed is the improvement of combination of the material usage that becomes the basic material.
\end{abstract}

\section{Key Words : Value Engineering, Performance, creat design}

\section{PENDAHULUAN}

Perkembangan industri kerajinan ukirukiran di Jepara dewasa ini menunjukkan prospek yang sangat cerah. Hal ini dapat dilihat dari semakin meningkatnya ekspor komoditi tersebut. Begitu pula halnya dengan kondisi didalam negeri dimana masyarakat semakin banyak yang menggemari produk-produk kerajinan ukirukiran tradisional baik itu dalam bentuk furniture, komponen-komponen bangunan tradisional, maupun benda-benda seni lainnya.

Arah dari perkembangan Arsitektur Jepara sendiri adalah menuju kepada Arsitektur Jepara yang modern tradisional, modern dalam arti memenuhi tuntutan fungsi masa kini, memenuhi persyaratan teknis, bila perlu dengan memanfaatkan kemajuan teknologi dan memenuhi selera estetika masa kini yang dilandasi oleh prinsipprinsip komposisi/estetika modern. Namun demikian harus tetap diusahakan untuk melestarikan nilai-nilai tradisional yang bermakna luhur serta mempertahankan identitas / citra budaya / Arsitektur (tradisional). Melihat perkembangan diatas maka kurang adanya improvisasi dari para pengrajin itu sendiri terutama dalam hal pengembangan desain dan kombinasi penggunaan material misalnya produkproduk furniture berukir yang yang ada sekarang hanya mengandalkan bahan dari kayu saja.

\section{TINJAUAN PUSTAKA}

\section{KONSEP PRODUK}

Philip Kotler (1992) mendefinisikan produk sebagai segala sesuatu yang bisa ditawarkan kepada pasar untuk diperhatikan, dimiliki, dipakai atau dikonsumsikan sehingga dapat memuaskan kebutuhan atau keinginan. Dari definisisi diatas 
jelas bahwa produk tidak hanya bersifat fisik/berwujud (tangible) tetapi juga bisa tidak terwujud (intangible) seperti jasa.

\section{PERANCANGAN DAN}

\section{PENGEMBANGAN PRODUK}

Mengembangkan produk baru berarti merubah teknologi menjadi suatu produk atau jasa untuk memenuhi kebutuhan manusia atau pemakai. Pengembangan suatu produk tidak harus berarti penemuan yang baru sekali (invention) namun lebih menekankan untuk merubah suatu penemuan kedalam suatu bentuk yang memberikan manfaat kepada pemakainya (Karl T, Ulrich dan Steven D, Eppinges, 1972).

\section{DEFINISI DAN STRATEGI UNTUK}

\section{MEMASUKI PASAR}

Proses yang sangat penting dalam menentukan strategi untuk memasuki pasar adalah dengan mengidentifikasikan besarnya peluang pasar yang akan dimasuki. Proses ini merupakan tahap yang sangat kritis dalam proses pengambilan keputusan.

\section{PROSES DESAIN}

Proses desain adalah suatu kegiatan yang bertujuan untuk memenuhi kebutuhan manusia dengan memanfaatkan kemajuan teknologi. Pada proses desain selalu menggunakan aplikasi dari prinsip-prinsip ilmu pengetahuan dengan memperhatikan beberapa faktor tertentu. Faktor-faktor yang demikian tersebut antara lain: faktor manusia, faktor waktu, faktor ekonomi, faktor hukum dan lain-lain.

\section{REKAYASA NILAI (Value Engineering)}

Value analisis digunakan pertama kali pada waktu perang dunia ke-II, saat itu perusahaan general Elektrik mengalami kekurangan material dan tenaga kerja untuk memproduksi komponenkomponen persenjataan untuk pesawat terbang. Untuk menghadapi kesulitan-kesulitan diatas, Lawrence D. Miles, salah seorang ahli perusahaan tersebut mengembangkan suatu sistem yang disebut analis nilai, yang dapat mengurangi biaya dan juga meningkatkan hasil produksi.

Setelah analisa nilai dikenal manfaatnya maka dimulailah untuk berbagai kegiatan produksi lainnya. Sejak saat itu sistem tersebut dikenal dengan nama Rekayasa Nilai ( Value Engineering ).

Ada beberapa definisi yang menjelaskan tentang Rekayasa Nilai diantaranya, Larry W Zimmerman dan Glen D. Hard mengemukakan :

" Rekayasa Nilai adalah suatu teknik menejemen yang menggunakan pendekatan sistematis untuk mencapai keseimbangan fungsional antara biaya, keandalan dan performance dari suatu sistem proyek".

Edward D. heller mengemukakan :

" Rekayasa Nilai adalah suatu teknik yang mengidentifikasikan fungsi-fungsi yang diinginkan dan menetapkan nilai-nilainya mengembangkan alternatif-alternatif untuk 
memenuhi fungsi-fungsi tersebut dengan biaya yang minimum".

Lawrence D. Miles mengemukakan :

" Rekayasa Nilai adalah suatu pendekatan yang bersifat kreatif dan sistematis dengan tujuan mengurangi atau menghilangkan biaya-biaya yang tidak diperlukan".

Dari definisi diatas terlihat bahwa Rekayasa nilai menggunakan suatu pendekatan sistematis untuk mendefinisikan fungsi-fungsi yang diinginkan dalam mendesain suatu sistem, produk atau jasa, mengukur performance dan fungsi-fungsinya, sehingga performansi akhir yang dihasilkan akan sama atau akan mendekati performansi yang diinginkan pemakai dengan pertimbangan biaya yang optimal.

Rekayasa Nilai bukan suatu proses pengurangan biaya dengan jalan menekan biaya desain dan mengurangi kualitas, keadaan serta penampilannya tetapi hasilhasil yang dicapai dalam Rekayasa Nilai dapat berupa alternatif, penggunaan bahan, desain baru dan sebagainya dengan pertimbangan alternatif atau desain tersebut memiliki nilai yang lebih baik.

\section{Rencana Kerja Rekayasa Nilai}

Rencana kerja rekayasa nilai terdiri atas lima tahap yaitu :

1. Tahap Informasi

2. Tahap Kreatif

3. Tahap Analisa

4. Tahap Pengembangan

5. Tahap Presentasi

\section{Analisa Morfologi}

Analisa morfologi memecahkan suatu masalah menjadi elemen-elemennya. Kemudian mengidentifikasikan sejumlah alternatif atribut untuk setiap elemen dan menyusun alternatif pemecahan dengan mengkombinasikan atributatribut dari setiap elemen yang berbeda.

\section{Analisa Fungsi \\ Analisa fungsi adalah teknik penyusunan diagram secara sistematis, untuk mengidentifikasikan fungsi-fungsi dan menggambarkan kaitan antara funsi-fungsi tersebut. Fungsi dinyatakan dalam Rekayasa Nilai.}

\section{Matriks Evaluasi}

Matriks ini merupakan alat pengambilan keputusan dari beberapa alternatif desain proyek atau produk dengan jalan mengkombinasikan kriteria kualitatif.

\section{Penentuan Tingkat Kontribusi Masing-masing} Kriteria

Dari data yang diperoleh melalui kuesioner, dilakukan pengolahan data untuk menentukan tingkat kontribusi masing-masing parameter. Pengolahan data ini dilakukan dengan tahapantahapan sebagai berikut:

\section{Uji Kecukupan Data}

Untuk mengetahui berapa jumlah observasi yang seharusnya dibuat (N'), maka perlu dilakukan test kecukupan data. Sebelum dilakukan test ini harus diputuskan terlebih dahulu beberapa tingkat kepercayaan dan derajat ketelitian didalam aktifitas pengukuran kerja, biasanya akan diambil 
$95 \%$ Convidence level dan $10 \%$ Degree of Accuracy. Hal ini sekurang-kurangnya 95 dari 100 harga rata-rata dari waktu yang dicatat atau diukur untuk elemen kerja akan memiliki penyimpangan tidak lebih dari $10 \%$. Rumus yang digunakan adalah:

$$
N=\left(\frac{k / s \sqrt{N \sum x-\left(\sum x\right)^{2}}}{\sum x}\right)
$$

Sumber: Sritomo (th. 1989, hal 96)

Dimana : $\mathrm{X}=$ Data bobot penilaian

$$
\mathrm{N}^{\prime}=\text { Jumlah pengamatan }
$$

seharusnya

$$
\mathrm{N}=\text { Jumlah pengamatan yang }
$$

ada

$$
\begin{aligned}
& \mathrm{K}=\text { Harga tingkat kepercayaan } \\
& \mathrm{S}=\text { Harga tingkat ketelitian }
\end{aligned}
$$

Apabila hasil yang diperoleh yaitu $\mathrm{N}^{\prime}$ lebih besar daripada $\mathrm{N}$, maka pengamatan harus ditambah sedemikian rupa sehingga data yang diperoleh kemudian bisa memberikan tingkat keyakinan dan tingkat ketelitian sesuai dengan yang diharapkan.

\section{Menentukan Nilai Uji Keseragaman}

\section{Data}

Langkah selanjutnya menentukan nilai rata-rata dan standart deviasi, dengan tujuan untuk mencari nilai dari masingmasing parameter. Dengan rumus:

$$
\mathrm{SD}=\sqrt{\frac{\sum(X i-X)^{2}}{n-1}}
$$

Sumber : Pengantar PKS "Douglas C. Montgomery"(hal:33).

Dan selanjutnya mencari batas control dari masing-masing parameter, dengan rumus
:BKA (Batas Kontrol Atas) $=\mathrm{X}+\mathrm{k} \sigma_{\mathrm{X}}$

$\mathrm{BKB}\left(\right.$ Batas Kontrol Bawah) $=\mathrm{X}-\mathrm{k} \sigma_{\mathrm{X}}$

Sumber : Study Gerak dan waktu, Sritomo Wignyosoebroto $(1995 ; 200)$

\section{Menentukan Bobot Kontribusi}

Bila data sudah dihitung dengan uji kecukupan data, nilai rata-rata, standart deviasi dan penghitungan batas control pengendali, maka langkah selanjutnya menentukan bobot kontribusi masing-masing parameter. Dengan rumus sebagai berikut:

$$
\% \text { Kriteria }(K r)=\frac{K i}{\sum K i} x 100 \%
$$

$$
\text { Dimana } \mathrm{i}=\text { Banyaknya item }
$$
pertanyaan

$$
\mathrm{Ki}=\underset{\text { Jumlah dari tiap-tiap item }}{\text { pertanyaan }}
$$

Sumber : Study Gerak dan waktu, Sritomo Wignyosoebroto $(1995 ; 223)$

\section{Pengujian Konsistensi Data}

pengujian konsistensi data dilakukan dengan metode analisis hirarki. Untuk perhitungannya dilakukan dalam beberapa tahap berikut: Dikalikan secara kumulatif. Kemudian hasil perkalioan dimasukkan dalam akar dengan derajat yang sesuai denagn jumlah elemen pada baris matrik.

* MenentukanMatrik

Perbandingan

\section{Berpasangan}

Matrik perbandingan berpasangan diperoleh dengan cara malakukan perbandingan berpasangan dari masing-masing parameter.

\section{* Menentukan Matrik Eigen Vektor}

Elemen pada masing-masing baris dari matrik hasil perbandingan berpasangan 
* Menentukan Eigen Value

\section{Maksimum}

Langkah pertama kali yaitu menentukan kolom baru, yang didapat dari perkalian antara matrik perbandingan berpasangan dengan matrik eigen vvektor. Selanjutnya menentukan eigen value yang merupakan hasil bagi antara elemen yang bersesuaian dari matrik kolom baru dengan eigen vector. Denagn rumus:

$$
\lambda \text { maks }=\frac{\sum \text { MatrkeigenValue }}{n}
$$

\section{* Menguji Konsistensi Data}

Untuk menguji konsisitensi data diketahui dari nilai Ratio Konsisitensi (CR) yang merupakan nilai bagi antara Indeks Konsisitensi (CI) dengan Indeks Random (CR). Dengan rumus sebagai berikut:

$$
\begin{aligned}
& \mathrm{CI}=\frac{\lambda m a k s-n}{n-1} \\
& \mathrm{CR}=\frac{C I}{C R}
\end{aligned}
$$

Jika nilai $\mathrm{CR} \leq 0,10$ maka dapat dianggap konsisitensi.

Sumber:AHP "PAU-EK-UI" (1992, hal: 16-17)

\section{Matriks Evaluasi}

Matriks Evaluasi adalah suatu teknik pengambilan keputusan yang dapat menggabungkan kriteria kualitatif dengan kriteria kuantitatif. Kritria-kriteria tersebut dapat berupa kekuatan bahan, biaya, keindahan, memudahkan pembuatan dan sebagianya. Pada metode ini digunakan metode numerik dengan memberikan bobot pada setiap kriteria da besarnya bobot yang diberikan harus sesuai dengan kepentingan kriteria. Bobot dari masingmasing kriteria ini didapat dari hasil pengolahan data yang pertama.

Langkah-langkah dalam Matriks

Evaluasi adalah sebagai berikut:

1. Menetapkan kriteria-kriteria yang berpengaruh

2. Menetapkan bobot masing-masing kriteria

3. Menentukan alternatif-alternatif desain yang akan dievaluasi

4. Memberikan penilaian pada setiap alternatif terhadap masing-masing kriteria dan penilaian dilakukan oleh beberapa orang dengan persyaratan tertentu.

5. Menghitung nilai total masing-masing alternatif

6. Memilih alternatif terbaik berdasarkan nilai total terbesar

\section{METODOLOGI PENELITIAN}

\section{Data yang Diperlukan}

Proses pengumpulam data I dilakukan dengan menyebarkan kuesiner sebanyak 100 buah. Dan pada akhirnya kembali atau terkumpul sebanyak 75 kuesioner yang telah terisi dengan benar.

* Struktur Fungsi Daun Pintu Ukir Jepara 


\section{Uji Kecukupan Data}

Dan dibawah ini adalah contoh perhitungan uji kecukupan data untuk kriteria kekuatan bahan baku (kayu) adalah $\mathrm{sbb}$ :

$$
\begin{aligned}
& \mathrm{N}^{\prime}=\left[\frac{\mathrm{k} / \mathrm{s} \sqrt{\mathrm{N} \sum \mathrm{X}^{2}-\left(\sum \mathrm{X}\right)^{2}}}{\sum \mathrm{X}}\right]^{2} \\
& N^{\prime}=\left[\frac{\frac{2}{10} \% \sqrt{75.678-(220)^{2}}}{220}\right]^{2} \\
& N^{\prime \prime}=\left[\frac{20 \sqrt{50850-48400}}{220}\right]^{2} \\
& N^{\prime \prime}=\left[\frac{20 \sqrt{2450}}{220}\right]^{2} \\
& N^{\prime \prime}=\left[\frac{989,94}{220}\right]^{2}=[4.499]^{2}=20,24 \\
& \mathrm{~N}^{\prime}=20,24 \\
& \mathrm{~N}^{\prime}<\mathrm{N} \text { maka data yang ada }
\end{aligned}
$$

dianggap sudah cukup.

\section{Tabel 1}

\section{Hasil Uji Kecukupan Data}

\begin{tabular}{|c|l|c|c|}
\hline No & \multicolumn{1}{|c|}{ Kriteria-kriteria } & N & $\begin{array}{c}\text { Keteran } \\
\text { gan }\end{array}$ \\
\hline 1 & Keawetan Bahan & 20,24 & Cukup \\
2 & Kekuatan Produk & 12,499 & Cukup \\
3 & Motif Ukir-ukiran & 4,9 & Cukup \\
4 & Pengerjaan Produk & 52,675 & Cukup \\
5 & Harga & 15,039 & Cukup \\
6 & Keserasian Warna & 59,185 & Cukup \\
7 & Praktis dlm Penggunaan & 31,531 & Cukup \\
8 & Mudah Perawatan & 33,501 & Cukup \\
\hline
\end{tabular}

\section{Menentukan Nilai Uji Keseragaman}

Data

Dan dibawah ini adalah contoh perhitungan batas kontrol untuk kriteria keawetan bahan baku (kayu) adalah sebagai berikut :

$$
\begin{aligned}
\text { BKA (Batas kontrol Atas) } & =2,9+2(0,66) \\
& =4,22 \\
\text { BKB (Batas Kontrol Bawah) } & =2,9-2(0,66) \\
& =1,58
\end{aligned}
$$

Dengan tingkat kepercayaan $95 \%$ maka $\mathrm{k}=2$.

Adapun hasil perhitungan untuk nilai rata-rata, uji keseragaman data dan perhitungan batas kontrol pengendali.

\section{Penentuan Bobot Kontribusi}

Bila data diatas seluruhnya berada dalam batas kontrol, maka selanjutnya dilakukan penentuan bobot kontribusi masing-masing parameter. Perhitungannya adalah sebagai berikut

$\therefore$ Kriteria $(K r)=\frac{K i}{\sum K i} \times 100 \%$

Dimana $I=1,2,3 \ldots 8$.

Perhitungan kontribusi untuk kriteria keawetan bahan baku (kayu) adalah sebagai berikut : \% Kriteria $(K r)=\frac{220}{1557} \times 100 \%$

\section{$\%$ Kriteria $(\mathrm{Kr})=14,13 \%$}

Adapun hasil perhitungan untuk penentuan tingkat kontribusi masing-masing parameter adalah sebagai berikut.

Tabel 2

\section{Nilai Masing-masing Kriteria}

\begin{tabular}{|l|l|c|}
\hline No & Parameter kriteria & $\mathbf{\%}$ \\
\hline 1 & Keawetan bahan (kayu) & 14,13 \\
2 & Kekuatan produk & 12,84 \\
3 & Motif ukir-ukiran & 14,45 \\
4 & Pengerjaan produk & 12,14 \\
5 & Harga & 12,33 \\
6 & Keserasian Warna & 12,59 \\
7 & Praktis penggunaannya & 10,79 \\
8 & Mudah perawatannya & 10,73 \\
\hline
\end{tabular}


Tabel 3

Nilai Uji Keseragaman Data

\begin{tabular}{|l|c|c|c|c|c|}
\hline \multicolumn{1}{|c|}{ Nomor Kriteria } & Kr & SD & BKA & BKB & Keterangan \\
\hline 1.Keawetan bahan (kayu) & 14,13 & 0,66 & 4,22 & 1,58 & Seragam \\
2.Kekuatan produk & 12,84 & 0,47 & 3,64 & 1,76 & Seragam \\
3.Motif ukir-ukiran & 14,45 & 0,00 & 3 & 3 & Seragam \\
4.Pengerjaan Produk & 12,14 & 0,92 & 4,34 & 0,66 & Seragam \\
5 Harga & 12,33 & 0,50 & 3,6 & 1,6 & Seragam \\
6 Keserasian Warna & 12,59 & 1,01 & 4,62 & 0,58 & Seragam \\
7.Praktis dalam & 10,79 & 0,63 & 3,46 & 0,94 & Seragam \\
penggumaan & 10,73 & 0,65 & 3,5 & 0,9 & Seragam \\
8. Mudah perawatan & & & & & \\
\hline
\end{tabular}

\section{Pengujian Konsisitensi Data}

\section{Menentukan Matriks Perbandingan Berpasangan}

Tabel 4

Matriks Perbandingan Berpasangan

\begin{tabular}{|c|c|c|c|c|c|c|c|c|}
\hline Prmt & $\mathbf{1}$ & $\mathbf{2}$ & $\mathbf{3}$ & $\mathbf{4}$ & $\mathbf{5}$ & $\mathbf{6}$ & $\mathbf{7}$ & $\mathbf{8}$ \\
\hline $\mathbf{1}$ & 1 & 3 & 5 & 2 & 5 & 3 & 2 & 2 \\
\hline $\mathbf{2}$ & $1 / 3$ & 1 & 3 & 3 & 2 & 2 & 2 & 4 \\
\hline $\mathbf{3}$ & $1 / 5$ & $1 / 3$ & 1 & 3 & 2 & 2 & 2 & 2 \\
\hline $\mathbf{4}$ & $1 / 2$ & $1 / 3$ & $1 / 3$ & 1 & 3 & 2 & 3 & 2 \\
\hline $\mathbf{5}$ & $1 / 5$ & $1 / 2$ & $1 / 2$ & $1 / 3$ & 1 & 2 & 2 & 3 \\
\hline $\mathbf{6}$ & $1 / 3$ & $1 / 2$ & $1 / 2$ & $1 / 2$ & $1 / 2$ & 1 & 2 & 2 \\
\hline 7 & $1 / 2$ & $1 / 2$ & $1 / 2$ & $1 / 3$ & $1 / 2$ & $1 / 2$ & 1 & 3 \\
\hline $\mathbf{8}$ & $1 / 2$ & $1 / 4$ & $1 / 2$ & $1 / 2$ & $1 / 3$ & $1 / 2$ & $1 / 3$ & 1 \\
\hline
\end{tabular}

\section{Menentukan Matrik Eigen Vektor}

Elemen-elemen pada masing-masing baris dari matrik hasil perbandingan berpasangan dikalikan secara komulatif. Kemudian hasil perkalian dimasukkan dalam akar dengan derajat yang sesuai dengan jumlah elemen pada baris matrik. Misalkan menentukan parameter desain motif ukir-ukiran dengan matrik baris $1,3,5,2,5,3,2,2$ maka matrik kolom $=(1 \times 3 \times 5 \times 2 \times 5 \times 3 \times 2 \times 2)^{1 / 8}=2,55$

Dengan cara yang sama akan diperoleh matrik kolom untuk menentukan matrik eigen vektor, diperoleh dengan cara membagi matrik kolom. Misalnya untuk elemen eigen vektor baris $(1)=2,55 / 9,22=0,276$.

Dengan cara yang sama maka akan diperoleh matrik eigen vektor.Matrik Kolom

\section{Kolom M E Vektor}

$$
\left[\begin{array}{l}
2,55 \\
1,77 \\
1,16 \\
1,09 \\
0,82 \\
0,73 \\
0,65 \\
0,45
\end{array}\right] \quad\left[\begin{array}{l}
0,276 \\
0,191 \\
0,126 \\
0,118 \\
0,089 \\
0,079 \\
0,070 \\
0,049
\end{array}\right]
$$

$\sum 9,22$

\section{Menentukan eigen value maksimum}

\section{KBaru MEVektor M E Value}

$$
\left[\begin{array}{l}
2,63 \\
1,69 \\
1,17 \\
1,09 \\
0,74 \\
0,67 \\
0,63 \\
0,45
\end{array}\right]\left[\begin{array}{l}
0,276 \\
0,191 \\
0,126 \\
0,118 \\
0,089 \\
0,079 \\
0,070 \\
0,049
\end{array}\right] \quad \frac{\left[\begin{array}{l}
9,53 \\
8,84 \\
9,28 \\
9,23 \\
8,31 \\
8,48 \\
9 \\
9,18
\end{array}\right]}{\sum 71,85}
$$

$\lambda$ maksimum $=\frac{\sum \text { Matrik EigenValue }}{\mathrm{n}}$ 
$\lambda$ maksimum $=\frac{71,85}{8}=8,98$

\section{Menguji konsistensi data}

Untuk menguji konsistensi data diketahui dari nilai ratio konsistensi (CR) yang merupakan hasil bagi antara indeks konsistensi (CI) dengan indeks random (RI). $\quad C I=\frac{\lambda m a k s-n}{n-1}$

$$
\begin{aligned}
& =\frac{8,98-8}{7}=0,14 \\
C R & =\frac{C I}{I R} \\
& =\frac{0,14}{1,41}=0,09
\end{aligned}
$$

Nilai $\mathrm{CR} \leq 0,10$ maka dapat dianggap konsisten.

Sumber : AHP "PAU-EK-UI" (1992, hal 16-17)

\section{Tabel 5}

\section{Jumlah Koresponden}

\begin{tabular}{|l|c|c|c|c|}
\hline Alternatif & \multicolumn{4}{|c|}{ Jumlah Koresponden } \\
\cline { 2 - 5 } & Estetika & $\begin{array}{c}\text { Konstruksi } \\
\text { Kuat }\end{array}$ & Praktis & $\begin{array}{c}\text { Proses } \\
\text { Produksi }\end{array}$ \\
\hline D Awal & 39 & 46 & 35 & 41 \\
\hline Desain I & 41 & 46 & 39 & 31 \\
\hline Desain II & 45 & 46 & 41 & 43 \\
\hline Desain III & 43 & 46 & 43 & 36 \\
\hline Desain IV & 37 & 46 & 41 & 28 \\
\hline Desain V & 42 & 46 & 38 & 34 \\
\hline
\end{tabular}

Perhitungan data diatas dengan urut-urutan sebagai berikut:
a. Perhitungan Performansi
b. Analisa Biaya
c. Perhitungan Nilai

1. Maka untuk desain awal adalah sebagai berikut:

$$
V=\frac{n x P o}{C o}=\frac{60034,1 x 40,179}{2.412 .110}=1,0000
$$

\section{Maka untuk desain I adalah} sebagaiberikut:

$$
V=\frac{n x P 1}{C 1}=\frac{60034,1 \times 40,877}{2.004 .960}=1,223
$$

3. Maka untuk desain II adalah sebagi berikut

$V=\frac{n x P 2}{C 2}=\frac{60034,1 x 44,233}{2.051 .290}=1,295$

4. Maka untuk desain III adalah sebagai berikut

$$
V=\frac{n x P 3}{C 3} \quad=\frac{60034,1 x 43,945}{2.086 .698}=1,264
$$

5. Maka untuk desain IV adalah sebagai berikut:

$$
V=\frac{n x P 4}{C 4}=\frac{60034,1 \times 39,187}{2.072 .940}=1,134
$$

6. Maka untuk desain $\mathrm{V}$ adalah sebagai

\section{berikut:}

$V=\frac{n x P 5}{C 5}$

Tabel 6

Value dari Alternatif Desain

\begin{tabular}{|c|l|c|c|c|}
\hline No & Alternatif & Pn & $\mathbf{C n}$ & Vn \\
\hline $\mathbf{1}$ & Desain Awal & 40,179 & 2.412 .110 & 1,000 \\
\hline $\mathbf{2}$ & Desain I & 40.877 & 2.004 .960 & 1,233 \\
\hline $\mathbf{3}$ & Desain II & 44,233 & 2.051 .290 & 1,295 \\
\hline $\mathbf{4}$ & Desain III & 43,045 & 2.086 .698 & 1,264 \\
\hline $\mathbf{5}$ & Desain IV & 39,187 & 2.072 .940 & 1,134 \\
\hline $\mathbf{6}$ & Desain V & 41,422 & 2.164 .950 & 1,148 \\
\hline
\end{tabular}

Dari hasil pengolahan data diatas maka pemilihan alternatif desain terbaik adalah alternatif desain II. 
Dari proses pengolahan data pada tahap sebelumnya, telah didapatkan sebuah desain baru yang merupakan alternatif terbaik dari keseluuruhan desain yang ada. Desain baru tersebutlah yang kemudian ditetapkan untuk diproduksi. Namun sebelum proses produksi dilaksanakan perlu dilakukan analisis lanjutan terlebih dahulu untuk mendapatkan masukanmasukan tambahan yang berguna dalam proses produksi nanti.

\section{Analisa Faktor Estetis}

Dari penelitian diatas maka didapatkan suatu desain baru. Desain baru ini ternyata memiliki nilai estetis yang lebih tinggi dibandingkan desai awalnya, disini terdapat perpaduan motigf dari Jepara yaitu motif bunga-bungaan yang dikombinasikan dengan motif kontemporer.

\section{Analisa Faktor Ergonomis}

Utilitas suatu produk menyangkut manfaat dan fungsi-fungsi yang dapat ditampilkan oleh produk tersebut. Maka dari itu untuk lebih menambah utilitasnya, maka produk pintu Jepara ini dilengkapi dengan handle pintu sehingga penggunanya menjadi lebih praktis.

\section{Analisa Faktor Ekonomis}

Pada penelitian ini tidak hanya diperhatikan segi estetis dan ergonomisnya saja, melainkan juga memperhatikan segi ekonomisnya yang mencakup upaya-upaya penekanan biaya produksi. Sehingga desain yang dihasilkan walaupun memilliki performansi yang lebih tinggi namun tidak menimbulkan tambahan biaya yang besar.

\section{Analisa Buat Atau Beli}

Dalam usaha mewujudkan desain baru ini menjadi sebuah produk jadi, tidak seluruh komponen atau bagian dari produk akan diproduksi sendiri. Beberapa bagian dari produk akan disubkontrakkan kepada produsen lain, dan sebagian lagi dibeli langsung pada toko-toko alat bangunan. Hal-hal yang menjadi pertimbangan antara lain adalah efisiensi waktu, efisiensi biaya dan keahlian yang diperlukan untuk membuat masing-masing bagian dari produk

\section{Proses Produksi}

Proses produksi yang ditekankan disini adalah proses produksi dalam skala industri yang merupakan proses fabrikasi dengan melibatkan penggunaan mesin-mesin pengolahan kayu yang modern dengan tujuan mempercepat proses produksi dan meningkatkan produktivitas perusahaan secara keseluruhan

Adapun tahapan-tahapan proses produksi serta bagian-bagian pekerjaan yang dilakukan adalah sebagai berikut:

* Tahap Pembuatan Kusen dan Daun Pintu

* Tahap Pengukiran

* Tahap Pembuatan Ornamen Kuningan

* Tahap Fionishing atau Lanjutan 


\section{KESIMPULAN}

1. Atribut-atribut daun pintu ukir Jepara yang baik berdasarkan preferensi konsumen adalah:

- Estetika

- Konstruksi kuat

- Praktis

- Proses produksi

2. Alternatif pintu Jepara yang terbaik berdasarkan penelitian ini adalah desain kedua yang memiliki spesifikasi seperti:

- Ukiran bermotif klasik dan dikombinasikan dengan ukiran kuningan.

- Bahan utamanya dari kayu jati.

- Warna coklat tua (agak gelap) kemerah-merahan.

\section{DAFTAR PUSTAKA}

Edward D Heller, 1971, Value Management : Value Engineering and Cost Reduction, Addison Wesley Publishing Company.

Lawrence D Milles, 1972, Techniqesn of Value Analysis and Engineering, Mc. Graw Hill Book Company.

Walpole, Ronald and Raymond H Meyers, 1986, Ilmu Peluang dan Statistika untuk Insinyur dan Ilmuwan, Institut Teknologi Bandung, Bandung.

Sudjana, M.A, Prof., DR, MSc, 1995, Desain dan Analisis Eksperimen, Edisi IV, PT. Tarsito, Bandung 